\title{
Explaining variation in the economic value of irrigation water using psychological capital: a case study from Ndumo B and Makhathini, KwaZulu-Natal, South Africa
}

\author{
S Phakathi' and E Wale ${ }^{2}$ \\ 'Department of Economics, Rhodes University, Grahamstown, 6139, Eastern Cape, South Africa \\ ${ }^{2} S$ chool of Agricultural, Earth and Environmental Sciences, Discipline of Agricultural Economics, University of KwaZulu-Natal, \\ Private Bag X01, Scottville, 3209, Pietermaritzburg 3201, South Africa
}

\begin{abstract}
This study investigates the economic value of irrigation water using data collected from 200 smallholder producers in Makhathini and Ndumo areas, KwaZulu-Natal.The study accounts for psychological capital (individual mind-set and attitude affecting motivation to take initiatives) as an important aspect of farm management. This concept focuses more on the 'soft' aspects of farm management, which have not been adequately studied in the context of smallholder farming. A sustainable livelihoods framework is employed as a conceptual framework and the role of psychological capital is integrated to explain the variation in water values. The study employs the residual valuation method to estimate water values, principal component analysis to generate an index for psychological capital, and the general linear model to explain variation in water values. The findings suggest that variation in water values was mainly influenced by the location of the farmer, farmer type, physical capital, social capital, land size, farming experience, crop type and psychological capital. The results reinforce the importance of institutional arrangements and collective bargaining as an important element of managing a smallholder farm to increase the economic value of water. To build and develop positive psychological capital for smallholders, it is recommended that government should re-visit the usual model of 'hand-outs' (input, finance). It is time to re-consider direct farmer support that entails being heavily involved in their day-to-day activities (i.e., purchasing inputs and running the irrigation schemes on their behalf). Going forward, the focus should rather be on enabling them to change their behaviour to be self-reliant and own their own destiny through on-farm and off-farm economic activities. Moreover, government and other development partners have to understand the long-term behavioural impact (on farmers) of what they do, for instance, entrenching expectations.
\end{abstract}

Keywords: economic value of irrigation water, psychological capital, residual valuation method, general linear model

\section{INTRODUCTION}

South Africa is regarded as the $30^{\text {th }}$ driest country in the world since it receives about half of the average annual global rainfall in terms of available water per capita (Cousins, 2013; Perret, 2002). Over $60 \%$ of the country receives less than $500 \mathrm{~mm}$ of rainfall per annum and about $21 \%$ receives less than 200 $\mathrm{mm}$ (Perret, 2002). Therefore, irrigation is important in South Africa because rainfall is unreliable, droughts are common and crop production in most of the country is inherently risky (Cousins, 2013).

South Africa has about 1.3 million hectares of land under irrigation and consumes an estimated 12.3 billion cubic meters of surface and groundwater per year (Perret, 2002). Of the total irrigated land, about 0.1 million hectares is in the hands of small-scale farmers that can be categorized into scheme and independent irrigators, community and home gardeners (Van Averbeke et al., 2011; Perret, 2002; Bembridge, 2000). The location of these small-scale irrigation projects is in the rural areas where poverty and food insecurity are concentrated, making them a strategic tool for the government to achieve its rural development goals. As a result, the South African Government has invested millions of Rands (ZAR) in their establishment, rehabilitation and revitalization (Hope et al., 2008; Bembridge, 2000). However, challenges still remain in the areas of collective management

\footnotetext{
To whom all correspondence should be addressed.

e-mail: sandiephakathi@gmail.com

Received 24 April 2017; accepted in revised form 25 September 2018
}

of the schemes, transfer of ownership, cost recovery, water distribution, productive use of water and meaningful impact on rural poverty. Despite consuming large volumes of water, the marginal value product of water in the small-scale sector is low by any standard (Muchara et al., 2016; Fanadzo et al., 2010; Yokwe, 2009). This is a major concern for policy makers due to rising water scarcity.

Government spends about 30 million USD/annum on maintenance and operational costs of irrigation schemes (Schreiner, 2015). The growing body of literature reveals that most smallholder irrigation projects in South Africa are still under-performing (Averbeke et al., 2011, Fanadzo et al., 2010; Yokwe, 2009), while others have totally collapsed. Irrigation is often given as a clear-cut example of failure of large-scale public investments in agriculture (Wiggins, 2005). Socio-economic, institutional, technical, climate and human capital, and social factors are reported as contributing to the weak performance of managing irrigation projects in South Africa (Juma and Spielman, 2014; Van Averbeke, 2012; Van Averbeke et al., 2011; Hope et al., 2008).

The empirical research adopting the sustainable livelihoods framework (SLF) so far accounts for access to physical, natural, financial, social and human capital assets as factors contributing to the poor performance of the schemes. SLF embraces that capital assets represent the capabilities available to households to follow different livelihood strategies (Chamber and Conway, 1991; DFID, 1999). For example, an area might have good rain and soils which represent an excellent farming opportunity. However, if a household does not possess, through ownership or otherwise, the assets that 
make farming possible, the result is failure to utilize the available opportunities. Non-viable land size is a major problem that hinders high economic value of water. The South African nationwide survey indicated that at least $25 \%$ of small-scale farmers are approaching landlessness as they control less than $0.11 \mathrm{ha} /$ capita (Jayne et al., 2010). The ability of this bottom land quartile to escape from poverty is directly constrained by access to land. Increased agricultural productivity, among others, depends primarily on formal education, indigenous knowledge and farming experience (Muchara et al., 2016). Human capital theory postulates that formal education is highly instrumental and essential as it increases the level of cognitive stock of economically productive human capability. However, human capital alone is not enough for increasing productivity because social capital creates networks, facilitating collaboration and coordination with other external groups to achieve set goals, and to enable individuals to have access to resources, information and support from organizations (Njuki et al., 2008). While the literature has linked the importance of capital assets to agricultural productivity, it is argued here that the role of psychological capital (PSYCAP) should be accounted for in explaining the economic value of water as PSYCAP is an important component of farm management (Makinen, 2013; Nuthall, 2001).

Based on authors' field observations and literature showing its role (Simon and Buitendach, 2013; Luthans et al., 2007; Luthans and Youssef, 2004), PSYCAP has been integrated to the SLF (see Fig. 1) to better explain why some farmers located in the same village are performing better than others, despite similarities in resource endowments and constraints. The empirical regularities of behavioural economics, especially the framing of decisions and how farmers behave, present significant challenges to traditional approaches to food security (Timmer, 2012). For example, Van Reenen and Davel (1986 p.1) describe concerns as to 'why some farmers are more successful than others'. 'Why do some farmers become affluent while those on neighbouring farms go bankrupt?' These observations entail similar questions this study is trying to answer in the context of smallholder farmers. Van Reenen and Davel (1986 p.1) argued that farmers' success (or otherwise) cannot be solely attributed to the availability of capital assets. They concluded that this asset must be 'management' (Van Reenen and Davel, 1986) which is acquired through formal education and/or experience and indigenous knowledge. According to Nuthall (2001), investigating the more central aspects of productivity, particularly on decision making, requires a psychological lens. This will enable better understanding of individual learning behaviour which is clearly related to management ability (Makinen, 2013). Hence, the concept of PSYCAP has been borrowed from disciplines of psychology and behavioural economics to better explain such differences across individual farmers in terms of farm management.

PSYCAP denotes individual mind-set and attitude, affecting motivation to undertake initiatives or otherwise which directly have an impact on productivity (Luthans et al., 2007). While social capital is about who you know (your networks), human capital is about what you know,

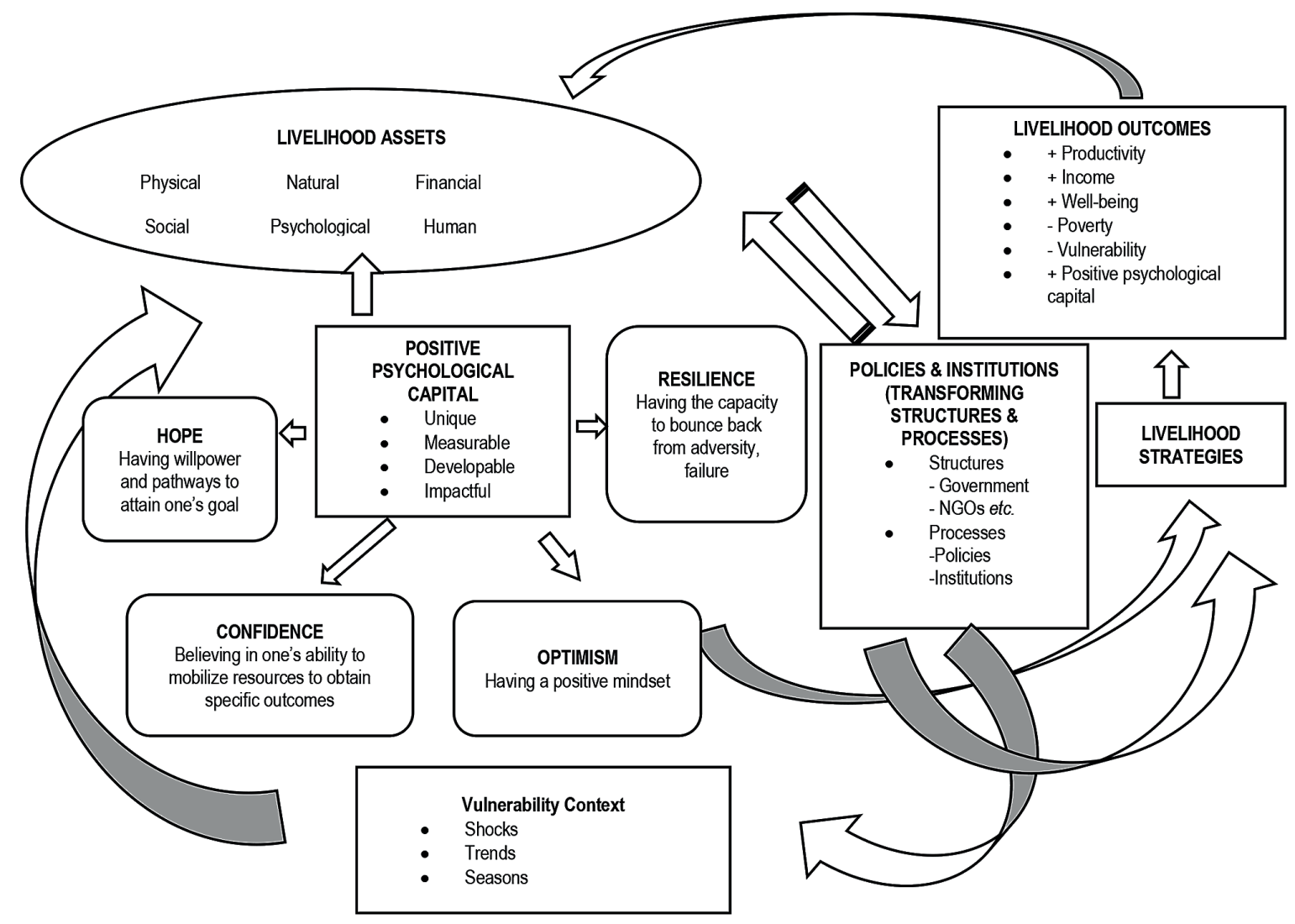

Figure 1

The modified SLF. Source: Adapted from DFID (1999) 
and PSYCAP is about who you are in terms of pursuing your objectives despite challenges. Positive PSYCAP has four dimensions: hope, optimism, resilience and confidence (Luthans et al., 2007; Luthans and Youssef, 2004). While hope is about having the willpower and pathways to attain one's goals, optimism is a question of having the explanatory style that attributes positive events to internal, permanent and pervasive causes. Resilience is about having the capacity to bounce back from adversity or failure, and confidence is a question of believing in one's ability (self-reliance), taking initiatives and mobilizing resources to obtain specific outcomes. According to Luthans and Youssef (2004), PSYCAP is unique, developable, drives motivation and impacts on performance. Individuals who have self-confidence persevere even when faced with obstacles, and are determined to succeed now and in the future. Optimistic individuals take obstacles as either challenges or opportunities to think differently so that the challenges can eventually be circumvented (Simon and Buitendach, 2013). They tend to bounce back and through hope they generate different pathways to accomplish goals (Luthans et al., 2007). The key is not to expect a different outcome from maintaining the status quo. When resources are limited and individuals are faced with constraints, those with positive psychological capital are more likely to do what they can with what they have and strive.

It is common knowledge that African small-scale farmers working in the same village, having a similar resource endowment (according to the five forms of capital) and faced with similar institutional and infrastructural constraints, are making decisions differently and achieving different levels of productivity and incomes (Chipfupa and Wale, 2018; Kruseman et al., 2006). While few take advantage of opportunities when they arise, many do not. While many wait and unduly expect government support (dependency syndrome), few make their own effort, take action and mobilize resources available. While few are confident in farming as a means of supporting household livelihoods, many are not. While many give up easily when faced with challenges, few do not. Such differences, in turn, will result in different livelihood outcomes. The question is how can one explain such differences? PSYCAP has been introduced to the SLF to capture such inherent individual mind-set differences that would naturally affect farm management. Why then do we want to link SLF, water values and psychological capital? If we understand how livelihood assets (including PSYCAP) affect productive use of water in smallholder agriculture, this knowledge will be an input not only for irrigation water use policy but also for rural development strategies aiming to improve agricultural production and productivity. The response variable in this study - the estimated residual value of water - is affected by agro-ecological, technical, policy and socio-economic factors that include markets. Thus, farmers with high positive PSYCAP endowment will exert more effort to address production, productivity and market access constraints. Even though the six forms of assets are conceptually distinct, they are not mutually exclusive as they are to some extent mutually re-enforcing. Moreover, this explanation is especially important in South Africa where unearned income (social grant and remittances) contributes more to total household income than smallholder farming. Given this background, the study aims to investigate the economic water values realised by smallholders in the Makhathini and Ndumo areas of KwaZulu-Natal.

\section{Why economic value of water?}

Water value is a measure of total output, divided by the amount of water used in production (Wichelns, 2015). Economists are often interested in maximizing the economic value of water used while plant breeders are more interested in maximizing kilograms of dry matter production per unit of transpiration. To an economist, it might mean the monetary value of output or gross margin divided by that of the necessary water input (Ali and Talukder, 2008). Such a definition based on economic value of agricultural water is more appropriate to economists because, at least in theory, it attempts to account for the opportunity cost of all resources outside water. Where agricultural water is provided free of charge, the outcome is expected to be poor management and inefficient use (Muchara et al., 2016) as there will be no incentive to use water wisely. Given the rising physical and economic water scarcity (Lautze et al., 2014), water has to be treated as an economic good (Young and Loomis, 2014; Zhanga et al., 2013) to ensure its sustainable use in agriculture (Molden et al., 2010; Hussain et al., 2007). The first step in that recognition is to value it. As to why this paper has not used physical water productivity to judge poor or bad use of irrigation water, see Wichelns (2015) and Zoebel (2006). However, it is advisable to always recognize that no single magic number represents the economic benefits of water (or any resource) used for any given sector (Young and Loomis, 2014). The value concept, such as the one used here, is focusing only on use and intrinsic values. The concept applied in this paper is of economic value of water, accounting for most input and output price differences.

\section{RESEARCH METHODOLOGY}

\section{Study area description}

Makhathini and Ndumo are located at Jozini Local Municipality within uMkhanyakude District. Jozini area is predominantly rural and extremely isolated as it is bounded to the east by the Indian Ocean, to the west by the Lebombo mountain range, and to the north by the border with Mozambique. These boundaries leave agricultural producers with restricted access to South African markets (UMkhanyakude District, 2012). The area has a humid subtropical climate with extremely hot weather conditions, thus making irrigation a major rural livelihood practice in farming. The Makhathini irrigation scheme is managed by Mjindi Farming, a government entity. On the other hand, Ndumo is managed by the farmers themselves. Makhathini irrigation scheme uses a canal system for irrigation and extracts water from Pongola River and Pongolapoort Dam while Ndumo B directly extracts water from the Pongola River using an electric pump. Independent irrigators are located near the Pongola River where they extract water while community gardeners are far away from the river, making it difficult to fetch water for irrigation and causing them to depend on small dams which usually dry up. Home gardeners often use tap water or fetch water from the nearest small dam (s). Figure 2 gives a map showing the two study areas.

The farmers in Ndumo do not pay for water, they only pay some of the capital invested, operation, and maintenance expenditure. However, in Makhathini irrigation scheme, farmers are charged an annual flat rate of $2700 \mathrm{ZAR} / \mathrm{ha}$ for water-related services; only $10 \%$ of this amount is for water fees 


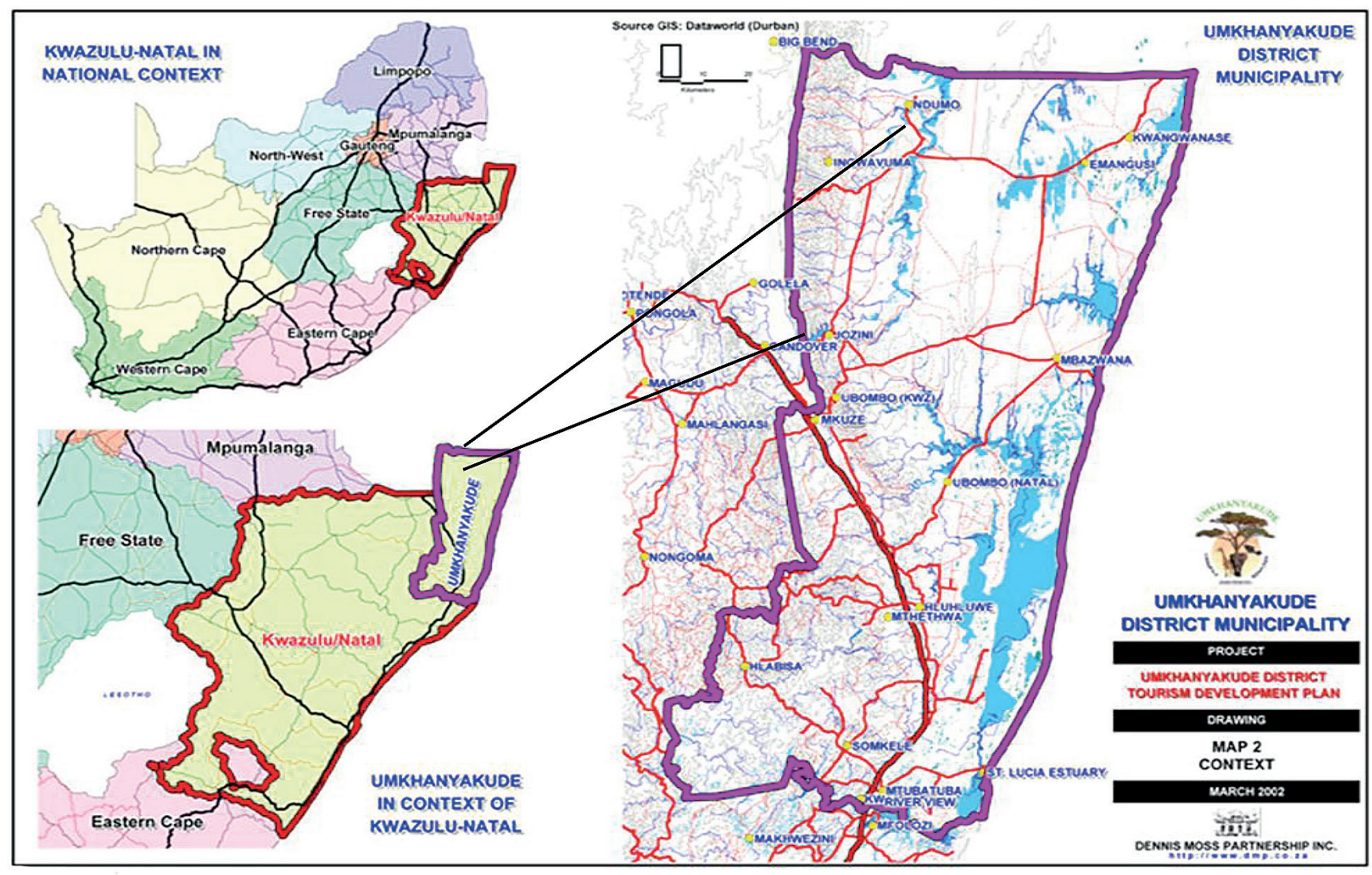

Figure 2

Map showing the study areas. Source: UMkhanyakude District (2012)

while the rest is for operational and maintenance expenditure. A significant amount of water and water-related service charges are being subsidized at Makhathini by the Government through Mjindi Farming, which is not the case in Ndumo B.

\section{Sampling procedure}

Data was collected from March to July 2015 by the first author with the assistance of trained local enumerators. A combination of purposive and stratified random sampling was employed to select the survey respondents. A list of the irrigation farmers was obtained from the provincial Department of Agriculture and Rural Development Office and farmers were further stratified according to their blocks and wards. The study purposively selected farmers who were engaged in food crop farming to make comparisons possible, as small farmers in Ndumo B mainly specialize in vegetable and cereal production while those in Makhathini also produce cotton and sugarcane. It is important to note that only those farmers who were practicing mono-cropping were purposively selected in order to calculate water values per crop, per plot, per farmer. After stratifying farmers, a simple random sampling was employed to draw a total sample of 200 farmers (89 scheme irrigators, 53 independent irrigators, 32 home gardeners and 26 community gardeners). Given the heterogeneity and population size, the sample in both schemes was considered appropriate. The sample is relatively small for the respective groups owing to the fact that the majority had not planted anything due to drought.

\section{Valuation of irrigation water in the context of smallholder farming}

There are various market and non-market methods to value water used in agriculture (Young and Loomis, 2014), the most common ones being contingent valuation, production function, hedonic pricing, choice experiments and residual valuation (Lange and Hassan, 2006). This study employs the residual valuation method. This non-market valuation method is widely used to determine the value of irrigation water as an intermediate good in production (Muchara et al., 2016). This method is more appropriate in this study as farmers in and around the irrigation schemes are producing for the market and the purpose of the analysis is to compare the economic value of water realized per crop, per farmer.

The residual value of water is estimated based on the theory that the value of output produced is the sum of the values of inputs employed in its production. The value of output per hectare can be written as follows:

$$
\begin{aligned}
Y^{*} P_{y}= & \left(V M P_{m}^{*} X_{m}\right)+\left(V M P_{c}^{*} X_{c}\right)+\left(V M P_{f}^{*} X_{f}\right)+\left(V M P_{l}^{*} X_{l}\right)+1 \\
& \left(V M P_{w}^{*} X_{w}\right)+\left(V M P_{t}^{*} X_{t}\right)
\end{aligned}
$$

Where $Y=$ yield (output $/$ ha); $P_{y}=$ output price; $V M P=$ value of marginal product of the respective inputs; and $X=$ quantity of respective inputs, the respective subscripts referring to: ${ }_{m}=$ machinery $(\mathrm{ZAR} / \mathrm{ha}),{ }_{c}=$ other non-fertilizer chemicals $(\mathrm{kg} /$ ha), $=$ fertilizers $(\mathrm{kg} / \mathrm{ha}),{ }_{l}=$ labour $(\mathrm{hr} / \mathrm{ha}),{ }_{w}=$ water in $\mathrm{m}^{3} / \mathrm{ha}$ and ${ }_{t}=$ transport (ZAR/kg per $\left.\mathrm{km}\right)$. Land was not costed since farmers were not paying for using land. 
The preceding equation can be expressed in terms of input prices because the opportunity cost of non-water inputs are given by their respective market prices (Young and Loomis, 2014).

$$
Y^{*} P_{y}=\sum_{i=j}^{n} P_{i} X_{i}+P_{w} * X_{w}
$$

On the right-hand side, the sum denotes the values of non-water inputs while the second term denotes the value of irrigation water (in cubic meters) with an unknown term $(P w)$. When the opportunity costs of non-water inputs are proxied by their respective market prices, the shadow price of water is then equal to the residual difference between the value of output and the cost of all non-water inputs (Young and Loomis, 2014). The residual valuation method aims to account for all the production costs and attribute the residual to water. This implies that the residual value is calculated as the difference between the total value and the cost of all non-water inputs.

Provided that we know the rest, the unknown, the residual claimant (water), can be given as:

$$
P_{w}=\frac{Y^{*} P_{y}-\sum_{i=j}^{n} P_{i} X_{w}}{X_{w}}
$$

Even though it may be simple to impute the residual value of water, it should be used with caution due to its sensitivity to small variation in the specification of the production function and its postulation about markets (Young and Loomis, 2014; Lange and Hassan, 2006). The inclusion of all crucial factors of production is fundamental in avoiding estimation biases in the residual value (Speelman et al., 2011). Due to the fact that fixed costs (such as land and other overhead costs) could not be accounted for because of lack of data, this could lead to over-estimation of the average water values. Thus, the water values estimated do not represent water prices. However, the over-estimation will be uniform for all plots and the procedure would not have an effect on the distribution of the residual values. Thus, residual value comparisons across farmers will not be affected and our failure to account for these costs will not affect the regression analysis.

\section{Data collection}

Primary data were collected using a pre-tested structured questionnaire. Focus group discussions and key informant interviews were held with farmers, extension officers and other stakeholders to supplement the survey data. Data collected included physical quantities of inputs, cost of inputs and outputs produced for the 2015 production season. Data on input and output usage including fertilizer, pesticides, labour and cost of all inputs used were collected on a weekly basis by trained graduated local enumerators to reduce recall problem and improve data quality. The actual prices farmers paid and received were used to calculate the respective cost of variable inputs and the revenue attained during each harvesting turn. Hired and family labour costs were calculated per activity because the costs of operation varied according to farming activities per crop (i.e. planting, harvesting, marketing, weeding, spraying etc.). Computation of hired labour cost involved collecting data on labour cost per activity (number of people ${ }^{\star}$ number of days* cost per day for each activity). Likewise, since family labour was not paid for, data was gathered on family labour employed for each activity and total cost per family labour was computed using the same wage rate paid for hired labour.
Farmers in the study area did not have any measuring devices for water applied, hence, the CROPWAT model was used to estimate crop water requirements (CWR) for crops grown. CWR is defined as the amount of water required to compensate the evapotranspiration loss from the cropped field (FAO, 2001; FAO, 2000). Rainfall data were acquired from the South African Weather Service, and the FAO PenmanMonteith method was used, which required data on radiation, air temperature, air humidity, wind speed data and crop coefficients. Since it was too expensive and time consuming to measure actual water applied for all farmers given the large sample, the authors acknowledged that water security among farmer type is different. Therefore, farmers were asked to scale their water security level using a 5-point Likert scale ( 1 = strongly water insecure, to 5 = strongly water secured). Then water quantities applied by farmers were estimated using the CROPWAT estimate multiplied by the level of their water security perception. Farmers who were strongly water secured were given the actual CWR estimate; those who felt that they were secured were given $80 \%$, neutral (60\%), insecure (40\%) and strongly insecure (20\%) of CWR, respectively. The total water requirement for these crops grown was computed using the evapotranspiration $\left(E T_{0}\right)$ and effective rainfall for each crop (FAO, 2001). Ethical clearance was approved by the University of KwaZulu-Natal to conduct this research.

\section{RESULTS AND DISCUSSION}

\section{Results on water values based on CROPWAT estimates}

Farmers grew various crops but the most common ones were maize (78 farmers), cabbage (54 farmers), beans (41) and tomatoes ( 27 farmers). Table 1 below presents water value estimates for these crops. The results show that water values in the study are highly variable based on crop type. Scheme irrigators had the highest water value for cabbage (14.06 ZAR/ $\mathrm{m}^{3}$ ), followed by independent irrigators for maize (9.51 ZAR/ $\left.\mathrm{m}^{3}\right)$, community gardeners for tomatoes $\left(1.43 \mathrm{ZAR} / \mathrm{m}^{3}\right)$ and home gardeners for cabbage $\left(0.90 \mathrm{ZAR} / \mathrm{m}^{3}\right)$. The estimated water values differ from studies in the past. For instance, Muchara et al. (2016) reported lower water values for cabbage $\left(0.47 \mathrm{ZAR} / \mathrm{m}^{3}\right)$, maize $\left(0.12 \mathrm{ZAR} / \mathrm{m}^{3}\right)$, and higher values for tomatoes $\left.\left(1.08 \mathrm{ZAR} / \mathrm{m}^{3}\right)\right)$ for Mooi River Irrigation Scheme. Speelman et al. (2011) reported higher values for beans (11.31 $\left.\mathrm{ZAR} / \mathrm{m}^{3}\right)$, and lower values for cabbage $\left(4.98 \mathrm{ZAR} / \mathrm{m}^{3}\right)$ and tomatoes $\left(3.12 \mathrm{ZAR} / \mathrm{m}^{3}\right)$ for small-scale farmers in NorthWest Province. The irrigation scheme yielded much higher water values for cabbage compared to other crops due to better market prices received through uMhlosinga, an NGO that holds the school feeding programme tender with the government. Farmers supplied their produce as a group to uMhlosinga to supply large quantities which they couldn't provide as individuals. These results are in line with Cia et al. (2011) who have shown the importance of guaranteed markets. Whilst some had access to better paying markets, others were obliged to sell their produce to their neighbours at a loss, below market prices, especially home and community gardeners.

For institutional reasons, scheme and independent irrigators were more water secured than community and home gardeners. That is why they managed to achieve higher water values. Tyler (2007) and Hussain and Hanjra, (2004), indicated that reliable access to irrigation water increases farmers' incentives to invest in high-yielding crop varieties which, in turn, increased productivity and greater returns from farming. 
TABLE 1

Economic valuation of water values (Note: Exchange rate was 1 USD1:12.4058 ZAR at June 2015)

\begin{tabular}{|c|c|c|c|c|}
\hline Farmers & $\begin{array}{c}\text { Average gross income } \\
\text { (ZAR/ha) }\end{array}$ & $\begin{array}{c}\text { Average total variable } \\
\text { cost (ZAR/ha) }\end{array}$ & $\begin{array}{c}\text { Average gross margin } \\
\text { (ZAR/ha) }\end{array}$ & $\begin{array}{c}\text { Water values } \\
\left(\mathrm{ZAR} / \mathrm{m}^{3}\right)\end{array}$ \\
\hline \multicolumn{5}{|l|}{ Maize $\left(\mathrm{CWR}^{1}=2612 \mathrm{~m}^{3 /} \mathrm{ha}\right)$} \\
\hline Scheme irrigators $(n=27)$ & 16185.48 & 15291.70 & 893.78 & 7.14 \\
\hline Independent irrigators $(n=24)$ & 17567.82 & 7313.63 & 10254.19 & 9.51 \\
\hline Home gardeners $(n=15)$ & 10408.44 & 13093.89 & -2685.45 & -3.17 \\
\hline Community gardeners $(n=12)$ & 4488.63 & 7876.70 & -3388.07 & -1.98 \\
\hline Total $(n=78)$ & 13700.33 & 11273.48 & 2426.85 & 4.48 \\
\hline \multicolumn{5}{|l|}{ Cabbage $\left(\mathrm{CWR}=3036 \mathrm{~m}^{3} / \mathrm{ha}\right)$} \\
\hline Scheme irrigators $(n=37)$ & 20478.20 & 18289.00 & 2189.20 & 14.06 \\
\hline Independent irrigators $(n=5)$ & 104732.00 & 173264 & -68532.00 & 7.27 \\
\hline Home gardeners $(n=7)$ & 14273.33 & 11081.19 & 3192.14 & 0.90 \\
\hline Community gardeners $(n=5)$ & 44822 & 38643.00 & -6179.00 & 0.007 \\
\hline Total $(n=54)$ & 35738.91 & 27243.27 & 8495.64 & 10.18 \\
\hline \multicolumn{5}{|l|}{ Beans $\left(\mathrm{CWR}=2601 \mathrm{~m}^{3} / \mathrm{ha}\right)$} \\
\hline Scheme irrigators $(n=22)$ & 20017.77 & 16021.89 & 3995.88 & 2.17 \\
\hline Independent irrigators $(n=11)$ & 9000.45 & 8945.18 & 55.27 & 0.11 \\
\hline Home gardeners $(n=5)$ & 8833.68 & 29894.00 & -21060.32 & -0.98 \\
\hline Community gardeners $(n=3)$ & 33000.00 & 31854.17 & 1145.83 & 4.76 \\
\hline Total $(n=41)$ & 16647.91 & 16973.44 & 325.53 & 0.66 \\
\hline \multicolumn{5}{|l|}{ Tomatoes (CWR = $\left.2617 \mathrm{~m}^{3} / \mathrm{ha}\right)$} \\
\hline Scheme irrigators $(n=3)$ & 102866.67 & 1670.33 & -13368.33 & -2.56 \\
\hline Independent irrigators $(n=24)$ & 17336.10 & 12342.72 & 4993.38 & 2.444 \\
\hline Home gardeners $(n=15)$ & 14520.00 & 40475.00 & -25955.00 & -4.39 \\
\hline Community gardeners $(n=6)$ & 37960.96 & 24815.00 & 13145.96 & 1.43 \\
\hline Total $(n=27)$ & 30901.30 & 19138.20 & -966.31 & 0.32 \\
\hline
\end{tabular}

'crop water requirement

While for community and home gardeners, uncertainties regarding how much water would be available resulted in low incentives to invest in improved inputs, resulting in farmers investing less in seeds and fertilizer. Furthermore, during the focus group discussions, other reasons for low levels of inputs, mainly for home and community gardeners, was high and unaffordable prices. However, the major bottleneck is the way in which they practice farming, buying inputs, acquiring services (such as tractor) and selling outputs individually, which directly increases transaction costs, relative to transacting as a co-operative or small informal group which is the case for most scheme irrigators. In general, negative gross margin signifies the poor performance of small-scale irrigation farmers in South Africa, despite government interventions.

Maize was profitable for independent and scheme irrigators because, on average, they operate larger plots. During the focus group discussions, it was noted that scheme irrigators in Makhathini had a marketing committee which sets prices for maize. The committee indicated that there is mistrust and not all farmers market and sell through this collective action arrangement. Most small farmers are forced to sell their maize right after harvest at lower prices as the opportunity cost of waiting for better prices and long-run profit margins was much higher due to immediate household financial needs (cash flow problem), lack of storage and market access uncertainty. Only a few risk-taking farmers took this opportunity and decided to wait for a future benefit in the long-run.

\section{Factors explaining variation in the economic value of water}

Table 2 below shows the variables used to estimate the general linear model which were selected using the modified SLF (Fig. 1 above).

The section below explains how the psychological capital indices were computed that were used as independent variables in the general linear model estimated.

\section{PSYCAP index computation and factor loading results}

Principal component analysis (PCA) was used to generate the PSYCAP index. PCA is a widely used data reduction technique that linearly transforms an original set of variables into a new set of uncorrelated variables called principal components (PC) that are ordered so that the first few PCs capture most of the variation present in all of the original variable (Jolliffe, 1986). The new information is expressed as a set of new orthogonal variables called principal components which are obtained as linear combinations of the original variables. To measure PSYCAP, farmers were asked to rate their level of PSYCAP endowment with respect to the four dimensions (Fig. 1) using a questionnaire (Table 3, Column 1) and their responses were coded in a 5-point Likert scale (see Table 2, Column 1). The scree plot was then used as a visual aid for assessing the number of PCs that can be extracted by graphing the eigenvalue 


\begin{tabular}{|c|c|c|}
\hline \multicolumn{3}{|c|}{$\begin{array}{c}\text { TABLE } 2 \\
\text { Variables identified to explain the value of water }\end{array}$} \\
\hline Variable designation & Variable description & \\
\hline \multicolumn{3}{|l|}{ DEPENDENT } \\
\hline$W_{v}$ & The estimated value of water $\left(\mathrm{ZAR} / \mathrm{m}^{3}\right)$ & \\
\hline INDEPENDENT & Coding & Proxy for \\
\hline FARMER LOCATION & $1=$ Makhathini $; 0=$ Ndumo & Institutional or community settings \\
\hline FARMER_TYPE & $1=$ Scheme irrigators; $0=$ otherwise & Type of farmer \\
\hline FINANCIAL_ASSET & $\begin{array}{l}\text { Access to financial capital } \\
1=\text { Yes; } 0=\text { No }\end{array}$ & Financial capital \\
\hline PHY_ASSET & Physical asset value (in Rands) & Physical capital \\
\hline LAND_SIZE & Size of land operated (in hectares) & Natural capital \\
\hline CROP_TYPE & $\begin{array}{l}\text { Type of crop grown } \\
1=\text { Cereals, } 0=\text { Vegetables }\end{array}$ & Capturing variation due to crop type \\
\hline SOCIAL_ASSET & $\begin{array}{l}\text { Way of practicing farming } \\
1=\text { Farm as a group; } 0=\text { Individually }\end{array}$ & Social capital \\
\hline MARKET_ACCESS & Walking distance to the nearest road (in minutes) & $\begin{array}{l}\text { Market access (capturing form of } \\
\text { vulnerability due to poor access to } \\
\text { market) }\end{array}$ \\
\hline GENDER & $1=$ Female; $0=$ Male & Gender differences \\
\hline$A G E$ & Age of a farmer & Human Capital \\
\hline$E D U \_L E V E L$ & Highest education level of farmers (in grades) & Human capital \\
\hline IRRIG_EXPER & Number of years in irrigation farming & Human capital \\
\hline CONFIDENT & $\begin{array}{l}\text { PSYCAP index } \\
\text { generated using PCA - self-reliance (confidence) }\end{array}$ & PSYCAP \\
\hline FARM_BY_DEFAULT & $\begin{array}{l}\text { PSYCAP index } \\
\text { generated using PCA - dependent on government }\end{array}$ & PSYCAP \\
\hline RISK_TAKERS & $\begin{array}{l}\text { PSYCAP index } \\
\text { generated using PCA - risk takers }\end{array}$ & PSYCAP \\
\hline
\end{tabular}

against the component number. The component number is taken to be the point at which the remaining eigenvalues are relatively small and all about the same size (Jolliffe, 1986). Based on the screen plot, only three PC's could be meaningfully interpreted and were therefore extracted and used as an index for psychological capital. Table 3 presents the results where $\mathrm{PC}_{1}$, $\mathrm{PC}_{2}$ and $\mathrm{PC}_{3}$ explained $29 \%, 10 \%$ and $9 \%$, respectively.

$\mathrm{PC}_{1}$ signifies farmers who are endowed with the four pillars of positive psychological capital. It captures farmers who are confident on farming as a means of maintaining household livelihoods and do not give up easily when there are obstacles but keep on pushing to achieve the goals set. Therefore, $\mathrm{PC}_{1}$ represents 'CONFIDENT' and self-reliant farmers endowed with hope and optimism. Their confident mindset and hope enables them to see the future in a positive light exercising the maximum effort to improve their livelihoods. According to Snyder (2002), hope helps to protect individual perceptions of vulnerability, uncontrollability and unpredictability as smallholder agriculture is highly susceptible to these calamities, owing to its nature-dependence. $\mathrm{PC}_{2}$ represents farmers that are the victims of dependency syndrome, with little self-reliance and assuming that Government is responsible for their wellbeing. $\mathrm{PC}_{2}$, therefore, represents a ' $F A R M_{-} B Y_{-}$ DEFAULT'. PC ${ }_{3}$ denotes a 'RISK_TAKER' willing to forgo quick and small benefits looking for more in the long-term. The results $\left(\mathrm{PC}_{1}\right.$ and $\left.\mathrm{PC}_{3}\right)$ indicate that indeed confidence, hope, capacity and willingness to take own initiative, perseverance, internal locus of control and risk-taking behaviour are the key dimensions of positive psychological capital. While $\mathrm{PC}_{1}$ and $\mathrm{PC}_{3}$ denote positive psychological capital endowment, $\mathrm{PC}_{2}$ denotes negative psychological endowment. These PCs were then all included in the regression model.

\section{Factor explaining variation in water values}

The GLM was employed to explain variation in water values because of its unique features which make it suitable whether the sample is balanced or unbalanced as it is a flexible generalization of ordinary least squares regression and allows for response variables that have an error distribution other than a normal distribution (Green and Wind, 1973). 'Partial eta squared', which measures the proportion of variance, was used to determine how big the effect is in the dependent variable that is explained by independent variable (s), controlling for all the other independent variables. An F-test was used to determine the fitness of the GLM model and it was accepted at $5 \%$ significance level.

The variable FARMER LOCATION accounted for about $12.4 \%$ of variation in water values as it signifies the importance of institutional or community setting. This result affirms Chancellor (1999) who argued that smallholder behaviour is affected by the diversity of local conditions such as land use and water access rights, infrastructure, local institutional arrangements and diverse traditional law(s) within a community. This variable captured such differences which have a major 
TABLE 3

Factor loading for PSYCAP index. Note: Five-point Likert scale values are: 1 = strongly disagree; 2 = disagree; $3=$ neutral; $4=$ agree; $5=$ strongly agree

\begin{tabular}{|c|c|c|c|}
\hline Variables & PC1 & $\mathrm{PC2}$ & $\mathrm{PC} 3$ \\
\hline I enjoy new challenges and opportunities & 0.770 & 0.010 & -0.018 \\
\hline I don't give up easily & 0.694 & -0.094 & -0.331 \\
\hline I am confident in farming as an economic activity & 0.684 & -0.016 & 0.082 \\
\hline I am confident in myself as a farmer & 0.679 & -0.241 & 0.047 \\
\hline I am willing to take more risk than other farmers in my community & 0.646 & 0.444 & 0.121 \\
\hline I have power to affect the outcome of my farming & 0.640 & 0.265 & 0.062 \\
\hline I trust other farmers & 0.630 & 0.375 & -0.214 \\
\hline I am optimistic about the future of agriculture in my area & 0.604 & -0.354 & 0.250 \\
\hline I have hope that the quality of life will get better & 0.596 & -0.264 & 0.032 \\
\hline I am able to cope with shocks such as drought and other natural disasters & 0.459 & -0.170 & -0.171 \\
\hline I would not be farming if I had an alternative source of income & 0.448 & 0.346 & 0.095 \\
\hline The government is responsible for the well-being of rural households & -0.140 & 0.664 & 0.143 \\
\hline I deal with problems as they arise rather than spend time to anticipate them & 0.102 & -0.219 & 0.147 \\
\hline $\begin{array}{l}\text { I am willing to forgo a profit opportunity in the short-run to benefit from potential profits in } \\
\text { the long-run }\end{array}$ & 0.005 & -0.251 & 0.676 \\
\hline I am passionate about my farm business & 0.154 & -0.334 & -0.350 \\
\hline$\%$ of variance explained & 29.035 & 10.375 & 9.31 \\
\hline
\end{tabular}

impact on productivity. FARMER_TYPE accounted for about $6.2 \%$, and indicated that being a member of an irrigation scheme came with certain benefits such as secured water access and input and output markets. Moreover, Government service providers give preferential treatment to scheme irrigators as most of them belong to a co-operative, making it relatively less time-consuming to reach them. This makes them receive necessary support (i.e. training, input procurements, and market access linkages). The majority of farmers outside the scheme (community and home gardeners) didn't receive much support from Government in terms of training and extension service). Hence, being in irrigation schemes seemed to enable farmers' to access inputs more cheaply and make them benefit more from their own produce, reducing input and output transaction costs, and increasing productive use of water. The variable $L A N D \_S I Z E$ accounted for about $2.9 \%$ in water value. This confirms that land size is one of the major bottlenecks that hinders farmers from achieving greater returns from water. The variable PHY_ASSET accounted for about $8.4 \%$ of variation in water values. Physical asset value was measured by asking farmers to put a value on all their physical assets which were important in production (tractor, phones, trailer, water tank, generator, plough etc.). The results confirm the importance of physical capital assets, and development in infrastructure for improved productivity.

The variable SOCIAL_ASSET accounted for about $4.2 \%$ in explaining water values. Farmers were asked in what form they practice farming (i.e. as a member of formal or informal group or as an individual) and this variable was used as a proxy for social capital. The results indicate that if farmers are transiting through as groups, purchasing inputs and selling output together, water values tend to increase because of reduction in transaction cost, enabling them to access inputs cheaper and making them benefit from their own produce. Moreover, farming as a group increases the chance of sharing or accessing information that

\begin{tabular}{|l|c|c|c|}
\hline \multicolumn{4}{|c|}{ TABLE 4 } \\
\hline Factors explaining variation in the economic water value \\
\hline Variables & $\boldsymbol{F}$ & $\boldsymbol{p}$-value & $\begin{array}{c}\text { Partial eta } \\
\text { squared }\end{array}$ \\
\hline Corrected model & $1.821^{\star *}$ & 0.021 & 0.360 \\
\hline Intercept & 0.143 & 0.706 & 0.002 \\
\hline FARMER LOCATION & $11.892^{* * *}$ & 0.001 & 0.124 \\
\hline FARMER_TYPE & $5.589^{* *}$ & 0.020 & 0.062 \\
\hline LAND_SIZE & $2.508^{*}$ & 0.117 & 0.029 \\
\hline PHY_ASSET & $7.673^{* * *}$ & 0.007 & 0.084 \\
\hline FINANCIAL_ASSET & 1.158 & 0.285 & 0.014 \\
\hline SOCIAL_ASSET & $3.701^{* *}$ & 0.058 & 0.042 \\
\hline GENDER & 1.465 & 0.230 & 0.017 \\
\hline AGE & 1.842 & 0.178 & 0.021 \\
\hline EDU_LEVEL & 1.105 & 0.367 & 0.136 \\
\hline IRRIG_EXP & $2.190^{*}$ & 0.143 & 0.025 \\
\hline CROP_TYPE & $2.973^{* *}$ & 0.088 & 0.034 \\
\hline MARKT_ACCESS & 0.492 & 0.485 & 0.006 \\
\hline CONFIDENCE & $4.978^{* *}$ & 0.028 & 0.056 \\
\hline FARM_BY_DEFAULT & 1.454 & 0.231 & 0.017 \\
\hline RISK_TAKERS & $4.649^{* *}$ & 0.034 & 0.052 \\
\hline Error & 185 & & \\
\hline Total & 200 & & \\
\hline Corrected total & 199 & & \\
\hline${ }^{* *}$ significantat 1\%; ${ }^{* *}$ significant at $5 \%{ }^{*}{ }^{*}$ significant at $10 \%$ \\
\hline
\end{tabular}


one could not have accessed as an individual. The education level of a farmer was not as significant as expected, compared to other studies (Muchara et al, 2016), but years of experience in irrigation farming was significant and accounted for about $2.5 \%$ of variation. More years of farming experience indicate that a farmer is more knowledgeable about farming operations received through training and lessons learnt from past experiences. The results are in line with Al-Karablieh et al. (2012) who investigated the economic value of irrigation water in Jordan and found that farmers' current decisions are subject to the results of past decisions and past events, such that decisions can be either extensive (land devoted to a crop) or intensive (application of fertilizers and other agro-chemicals). Therefore, experience is used as a pathway to success and prepares farmers on how to tackle different challenges in farming. The variable CROP_TYPE accounted for about $3.4 \%$ of the variability in water values. PSYCAP index for CONFIDENT FARMER and RISK_TAKER accounted for about $5.6 \%$ and $5.2 \%$ of variation in water value, respectively. The study results show the importance of PSYCAP in making use of available resources, opportunities and getting the best value for money from those resources. Given the prevailing constraints, available resources and capability endowments, farmers with positive PSYCAP tend to perceive problems and setbacks as challenges that are manageable and take advantage of opportunities (risk loving) that can eventually lead to success (Luthans et al. 2007).

\section{Conclusions and implications for irrigation water policy and management}

Given the increasing water scarcity problem that South Africa is facing, farmers, Government, and private organisations have an equal responsibility in ensuring improved water values in smallholder farming sector. Government needs to implement sound strategies to enable farmers to productively use irrigation water because the poverty of gross margins attained clearly indicates the poor return on the investment in irrigation infrastructure. Farmers have to take responsibility in collectively managing the irrigation schemes. Transformation in policies and institutional processes is required in how Government and private organisations offer services to farmers in order to eliminate the dependency syndrome that has (over the years) resulted in negative psychological capital. For example, the Government has been handing out inputs and cash to farmers, instead of enabling them to be self-reliant. The Government's responsibility should focus on providing public goods and services such as infrastructure development (roads, electricity, communication infrastructure, etc.) so that farmers can have better access to markets. Therefore, moving forward, to increase the psychological capital endowment of smallholder farmers, it is recommended that Government should reconsider the usual model of 'hand-outs' (inputs, finance, etc.) which has entrenched a dependency behaviour. There is a need to re-visit direct farmer support by being more heavily involved in their day-to-day activities (i.e. purchasing inputs, running the irrigation schemes on their behalf, etc.). The strategy should rather look forward and aim to enable farmers to change their behaviour to be self-reliant and own their own destiny through on-farm and off-farm economic activities. This will reduce their dependency. The results indicated that, among other proxies for human capital, experience is a significant factor in influencing water values. Hence, experienced farmers can transfer skills through various means such as workshops, where platforms with successful farmers can be created for experience sharing and motivation which will build confidence, hope, optimism, and resilience and directly increase the level of social capital among farmers and the community at large.

The results indicated that scheme irrigators achieved better levels of water values compared to non-scheme irrigators since they are transacting in groups as cooperatives which have enabled them to bargain and receive more support in terms of accessing training, inputs, and services. The results show that social capital is vital in collective management of irrigation water use. It can be recommended that home and community gardeners and independent irrigators should run their farming operations collectively in small groups (through purchasing inputs and selling output collectively in order to be able to supply in large quantities; this can directly address land size challenges. Building trust for collective action is key to building institutions and groups set up to achieve common objectives and enabling farmers to take advantage of collective bargaining, input, and output price negotiations, reaping the benefits of economies of scale and reducing transaction costs of accessing inputs and services.

Going forward, there is a need for conducting a study on the measurement and role of PSYCAP in rural livelihoods using other methods such as revealed preference approach, experimental economics and behavioural economics.

\section{ACKNOWLEDGEMENTS}

The authors would like to thank the Water Research Commission (WRC) for funding this study which was undertaken as part of a project (K5/2278/4) titled 'Water use productivity associated with appropriate entrepreneurial development paths in the transition from homestead food gardening to smallholder irrigation crop farming in KwaZuluNatal Province'. The project final report is available at www. wrc.org.za as 'WRC Report No. 2278/1/18 (May 2018)'.

\section{REFERENCES}

ALI MH and TALUKDER MS (2008) Increasing water productivity in crop production. Agric. Water Manage. 95 1201-1213. https://doi. org/10.1016/j.agwat.2008.06.008

AL-KARABLIEH EK, SALMAN AZ, AL-OMARI AS, WOLFF PH, AL-ASSAD TA, HUNAITI DA and SUBAH AM (2012) Estimation of the economic value of irrigation water in Jordan. J. Agric. Sci. Technol 2 2487-2497.

BEMBRIDGE T (2000) Guidelines for rehabilitation of small-scale farmer irrigation schemes in South Africa. WRC Report No. 891/1/00. Water Research Commission, Pretoria.

CAI X, MOLDEN D, MAINUDDIN MB, AHMAD M, and KARIMI P (2011) Producing more food with less water in a changing world: assessment of water productivity in 10 major river basins. Water Int. 36 (1) 42-62. https://doi.org/10.1080/02508060.2011.542403

CHAMBERS R and CONWAY GR (1991) Sustainable Rural Livelihoods: Practical Concepts for the 21st Century. Institute of Development Studies DP 296. University of Sussex, Brighton.

CHANCELLOR F (1999) Smallholder irrigators: Economic challenges and tools. Agrekon 38 (1) 259-268. https://doi.org/10.1080/0303185 3.1999.9524920

CHIPFUPA U and WALE E (2018) Farmer typology formulation accounting for psychological capital: Implications for on-farm entrepreneurial development. Dev. Pract. 28 (5) 600-614. https:// doi.org/10.1080/09614524.2018.1467377

COUSINS B (2013) Smallholder irrigation schemes, Agrarian reform and accumulation from above and from below in South Africa. J. Agrar. Change 13 (1) 116-139. https://doi.org/10.1111/joac.12000

DFID (Department for International Development) (1999) Sustainable livelihoods guidance sheets. DFID, London.

FANADZO M, CHIDUZA C, MNKENI P, VAN DER STOEP I, and 
STEVENS J (2010) Crop production management practices as a cause for low water productivity at Zanyokwe irrigation scheme. Water SA 36 (1) 177-189. https://doi.org/10.4314/wsa.v36il.50904

FAO (Food and Agriculture Organization of the United Nations) (2000) Crop Evapotranspiration. Guidelines for computing crop water requirements. Water Resources, Development and Management Service. Irrigation and Drainage Paper, No 56. FAO, Rome.

FAO (Food and Agriculture Organization of the United Nations) (2001) Smallholder irrigation technology: Prospects for subSaharan Africa. International Programme for Technology and Research in Irrigation and Drainage Knowledge Synthesis. Report No. 3. IPTRID Secretariat, Rome.

GREEN PE and WIND Y (1973) Multi-attribute decisions in marketing: A measurement approach. Hinsdale. III Dryden Press, New York.

HOPE RA, GOWING JW, and JEWITT GPW (2008) The contested future of irrigation in African rural livelihoods: Analysis from a water scarce catchment in South Africa. Water Polic. 10 173-192. https://doi.org/10.2166/wp.2008.061

HUSSAIN I and HANJRA A (2004) Irrigation and poverty alleviation: review of the empirical evidence. Irrig. Drain. 53 1-15. https://doi. org/10.1002/ird.114

HUSSAIN I, TURRAL H, MOLDEN D and AHMAD M (2007) Measuring and enhancing the value of agricultural water in irrigated river basins. Irrig. Sci. 25 263-282. https://doi.org/10.1007/ s00271-007-0061-4

JAYNE TS, MATHER D and MGHENYI E (2010) Principal challenges confronting smallholder agriculture in Sub-Saharan Africa. World Dev. 38 (10) 1384-1398. https://doi.org/10.1016/j. worlddev.2010.06.002

JOLLIFFE IT (1986) Principal Component Analysis. Springer-Verlag Inc., New York. https://doi.org/10.1007/978-1-4757-1904-8

JUMA C and SPIELMAN D (2014) Farmers as entrepreneurs: Sources of agricultural innovation in Africa. In: Hazell PBR and Rahman A (eds) New Directions for Smallholder Agriculture. Oxford University Press, New York. 201-210. https://doi.org/10.1093/acprof :oso/9780199689347.003.0012

KRUSEMAN G, RUBEN R and TESFAY G (2006) Diversity and development domains in the Ethiopian Highlands. Agric. Syst. 88 (1) 75-91. https://doi.org/10.1016/j.agsy.2005.06.020

LANGE GM and HASSAN R (2006) The Economics of Water Management in Southern Africa. An Environmental Accounting Approach. Edward Elgar Publishing House, United Kingdom.

LAUTZE J, CAI X and MATCHYA G (2014) Water productivity. In: Lautze J (ed.) Key Concepts in Water Resource Management: A Review and Critical Evaluation. Routledge, New York. 5-73. https:// doi.org/10.4324/9781315884394

LUTHANS F and YOUSSEF CM (2004) Human, social, and now positive psychological capital management: Investing in people for competitive advantage. Org. Dyn. 33 (2) 143-160. https://doi. org/10.1016/j.orgdyn.2004.01.003

LUTHANS F, AVOLIO BJ, AVEY JB and NORMAN SM (2007) Positive psychological capital: Measurement and relationship with performance and satisfaction. Pers. Psychol. 60 541-572. https:// doi.org/10.1111/j.1744-6570.2007.00083.x

MOLDEN D, OWEIS T, STEDUTO P, BINDRABAN P, HANJRA MA and KIJNE J (2010) Improving agricultural water productivity: Between optimism and caution. Agric. Water Manage. 97 (4) 528-535. https://doi.org/10.1016/j.agwat.2009.03.023

MAKINEN H (2013) Farmer's managerial thinking and management process effectiveness as factors of financial success on Finnish dairy farms. Agric. Food Sci. 22 452-465. https://doi.org/10.23986/afsci.8147

MUCHARA B, ORTMANN G, MUDHARA M and WALE E (2016) Irrigation water value for potato farmers in the Mooi River irrigation scheme of KwaZulu-Natal, South Africa: A residual value approach. Agric. Water Manage. 164 243-252. https://doi. org/10.1016/j.agwat.2015.10.022

NJUKI JM, MAPILA M, ZINGORE, S and DELVE R (2008) The dynamics of social capital in influencing use of soil management options in the Chinyanja Triangle of Southern Africa. Ecol. Soc. 13 (2) 9-24. https://doi.org/10.5751/ES-02539-130209

NUTHALL PL (2001) Managerial ability - A review of its basis and potential improvement using psychological concepts. Agric. Econ. 24 247-262.

PERRET S (2002) Water policies and smallholding irrigation schemes in South Africa: A history and new institutional challenges. Water Polic. 4 (3) 283-300. https://doi.org/10.1016/S1366-7017(02)00031-4

SCHREINER B (2015) Water pricing: the case of South Africa. In: Dinar A, Pochat V, Albiac-Murillo J (eds) Water Pricing Experiences and Innovations. Global Issues in Water Policy Vol 9. Springer, Cham. https://doi.org/10.1007/978-3-319-16465-6_15

SIMONS JC and BUITENDACH JH (2013) Psychological capital, work engagement and organisational commitment amongst call centre employees in South Africa. S. Afr. J. Ind. Psychol. 39 (2) 1071-1082.

SNYDER CR (2002) Hope theory: Rainbows in the mind. Psychol. Inq. 13 (4) 249-275. https://doi.org/10.1207/S15327965PLI1304_01

SPEELMAN S, FRIJA A, PERRET S, D'HAESE M, FAROLFI S and D'HAESE L (2011) Variability in smallholders' irrigation water values: Study in North-West Province, South Africa. Irrig. Drain. 60 (1) 11-19. https://doi.org/10.1002/ird.539

TIMMER P (2012) Behavioral dimensions of food security. Proc. Natl Acad. Sci. 109 (31) 12315-12320. https://doi.org/10.1073/ pnas.0913213107

TYLER S (2007) Water demand management, poverty and equity. IDRC Water Demand Management Research Series Working Paper 2. International Development Research Centre (IDRC), Amman.

UMKHANYAKUDE DISTRICT MUNICIPALITY (2012) Integrated Development Plan (IDP). Annual Review for 2011/12.

VAN AVERBEKE W, DENISON J and MNKENI P (2011) Smallholder irrigation schemes in South Africa: A review of knowledge generated by the Water Research Commission. Water SA 37 (5) 797-808. https://doi.org/10.4314/wsa.v37i5.17

VAN AVERBEKE W (2012) Performance of smallholder irrigation schemes in the Vhembe District of South Africa. In: Kumar MD (ed.) Problems, Perspectives and Challenges of Agricultural Water Management. InTech, Rijeka, Croatia.

VAN REENEN MJ and DAVEL JAH (1986) Farm Management. A Business Approach. The World Shop Publication Bureau, cc Hatfield. University of South Africa, Muckleneuk, Pretoria. 353 pp.

WICHELNS D (2015) Water productivity and food security: considering more carefully the farm-level perspective. Food Security 7 247-260. https://doi.org/10.1007/s12571-015-0426-0

WIGGINS S (2005) Success stories from African agriculture: what are the key elements of success? IDS Bull. 36 (2) 17-22. https://doi. org/10.1111/j.1759-5436.2005.tb00190.x

YOKWE S (2009) Water productivity in smallholder irrigation schemes in South Africa. Agric. Water Manage. 96 (8) 1223-1228. https://doi.org/10.1016/j.agwat.2009.03.012

YOUNG RA and LOOMIS JB (2014) Determining the Economic Value of Water: Concepts and Methods ( $2^{\text {nd }}$ edn). RFF Press: Resources for the Future, Washington, DC.

ZHANG L, HEERINK N, DRIES L and SHI X (2013) Water users associations and irrigation water productivity in northern China. Ecol. Econ. 95 128-136. https://doi.org/10.1016/j. ecolecon.2013.08.014

ZOEBL D (2006) Is water productivity a useful concept in agricultural water management? Agric. Water Manage. 84 265-273. https://doi. org/10.1016/j.agwat.2006.03.002 